\title{
Plant Allergen-Induced Contact Dermatitis
}

\author{
Authors \\ Philipp R. Esser ${ }^{1}$, Sabine Mueller ${ }^{2}$, Stefan F. Martin ${ }^{1}$ \\ Affiliations \\ 1 Allergy Research Group, Department of Dermatology, \\ Medical Center - University of Freiburg, Faculty of \\ Medicine, University of Freiburg, Germany \\ 2 Clinical Allergology, Department of Dermatology, Medical \\ Center - University of Freiburg, Faculty of Medicine, \\ University of Freiburg, Germany \\ Key words \\ allergy, contact dermatitis, plant-induced contact dermatitis, \\ case report, mechanism, review \\ received November 23, 2018 \\ revised March 7, 2019 \\ accepted March 8, 2019 \\ Bibliography \\ DOI https://doi.org/10.1055/a-0873-1494 \\ Published online March 15, 2019 | Planta Med 2019; 85: 528- \\ 534 (c) Georg Thieme Verlag KG Stuttgart · New York | \\ ISSN 0032-0943 \\ Correspondence \\ Dr. rer. nat. Philipp R. Esser \\ Allergy Research Group, Department of Dermatology, \\ Medical Center - University of Freiburg \\ Hauptstrasse 7, 79104 Freiburg im Breisgau, Germany \\ Phone: + 4976127068580 \\ philipp.esser@uniklinik-freiburg.de
}

\begin{abstract}
Although manifold beneficial effects of plant compounds for the treatment of skin disorders are known, cutaneous exposure to plants can also result in various types of incompatibility reactions such as contact dermatitis. In this mini-review, we briefly describe the different clinical forms of contact dermatitis (photoinduced, irritative, and allergic form) and highlight recent publications in the field of contact dermatitis. Major topics are recent recommendations regarding testing for plant contact dermatitis, advances in understanding the immunological mechanisms of plant contact dermatitis, and case reports for plant contact dermatitis. Unfortunately, most people still associate the terms "healthy and safe to use" with plant compounds due to their natural origin, leading to an increased utilization, be it for home-made remedies or as cosmetics. Therefore, it is on the one hand important to raise awareness in a broad audience that plants may cause contact dermatitis and on the other hand to indicate to clinicians that plants should be included in a patch test if a history of plant exposure exists.
\end{abstract}

\section{Introduction}

Plants and plant products are ubiquitous in our daily life, be it at homes, in gardens, at workplaces, or in nature. Despite the broad applicability of different plant compounds in the treatment of (skin) diseases (see further articles in this issue), as well as most plants being harmless on contact with the skin or ingestion, cutaneous exposure to plants can also cause incompatibility reactions such as contact dermatitis. This observation is also true for thedue to their perceived safety-increasing use of essential oils and botanical products that are included for example in cosmetics [1, 2]. Importantly, the risk of sensitization to essential oils increases with the concentration of the oil as well as with the presence of oxidation products such as epoxides or peroxides in the oil [3-5]. This indicates that these oils might become a stronger sensitizer with increasing age/autoxidation [6]. At least limonene seemed to be astonishingly stable under real-life conditions in a study ana- lyzing the formation of primary and secondary oxidation products in consumer products that were used for over 2 y [7]

The age distribution of patients with positive patch tests to topical herbal remedies $(1.4 \%$ patients with positive reactions out of the contact allergic subjects studied; $0.8 \%$ of the total study population) indicates that patients below 20 and over $69 \mathrm{y}$ old seem to be slightly less affected and that the majority of positive patients were female (93 compared to 34 men) [8]. Unfortunately, due to the limited number of commercially available standardized patch test substances and the risk of de novo sensitization when directly applying (parts of) plants or extracts, testing for plant-induced allergic contact dermatitis (ACD) still remains difficult.

Sensitization in higher numbers seems to occur only to a few plant families, with about 250 recognized contact-sensitizing plant families with medicinal properties in Europe [9] and more than 10000 species causing irritative or ACD worldwide [10]. The 
high relevance of plant-mediated contact dermatitis is underlined by data provided by the Information Network of Departments of Dermatology (IVDK), where fragrance mix (9.1\%), balsam of peru (7.2\%), fragrance mix II (4.6\%), rosin (3.9\%), ylang-ylang oil (2.4\%), compositae mix II (1.2\%), and sandal wood oil (2.2\%) were among the top 25 "hit list" of contact allergens in the patch test cohort 2012 [11]. - Table 1 provides a selected overview of sensitizing plant compounds and prevalence data. Apart from direct contact with plants/extracts mentioned above, even not so obvious routes of contact with sensitizing plant compounds may play a role in the development of skin reactions in extremely sensitive patients, as recently shown for the highly sensitizing sesquiterpene lactone (SL) parthenolide, occurring in plants of the Asteraceae family, which was found in Danish biodynamic and organic milk [12].

As indicated by a recent approach to develop a quantitative risk assessment model for skin sensitizing plant protection products [16], not only plants or plant compounds themselves but also plant protection products need to be taken into account regarding the elicitation of contact dermatitis after plant contact.

\section{Clinical Forms of Plant-Induced Contact Dermatitis}

Apart from mechanical injury due to splinters or abrasions, which usually do not come to the attention of physicians, although they represent a frequent cause of plant dermatitis, plants can cause more severe skin dermatoses. Co-exposure of the skin with plant compounds and UV-light may lead to phototoxic/irritative or photoallergic reactions. Toxic/irritative reactions result from an activation of the innate immune response while photoallergic reactions require the activation of the adaptive immune response. Both irritative-, immediate-, or late-type ACD reactions can occur even without UV radiation of the skin just by contact to the plant, analogous to the irritative or ACD observed after contact with irritative or sensitizing chemicals. A special form of contact dermatitis, the airborne contact dermatitis ( $A B C D$ ), is induced by exposure to particles suspended in the air. Due to the general difficulty to prove the diagnosis, it is difficult to determine the exact prevalence of $A B C D$. Again, $A B C D$ can be classified either as allergic or as irritative contact dermatitis, depending on the etiology and mechanism of inflammation. A recent case of $A B C D$ in 2 patients showing allergic reactions to Eucalyptus L'Her. was published by Paulsen et al., also indicating that the exact identification of an $A B C D$ was difficult [17].

A rare non-eczematous form of contact dermatitis was reported in a patient receiving acupoint herbal patch therapy with Semen Sinapis Albae (SSA) from Sinapis alba L. [18]. In this patient, patches were applied twice in an interval of $10 \mathrm{~d}$ with no cutaneous abnormalities observed $24 \mathrm{~h}$ after removal of the second patches. However, 1 mo later, pruritic erythema and pin-sized papules appeared at the application site; a skin biopsy showed parakeratosis, acanthosis, and focal spongiosis in the epidermis. The patient was diagnosed with lichenoid contact dermatitis induced by SSA [18].

\section{Recent Recommendations Regarding Testing for Plant Contact Dermatitis and Novel Classifications}

While contact dermatitis to plants has been well known for a long time and been extensively documented in several impressive works such as the book by Mitchell and Rook [10], it is still of relevance nowadays. In general, the prevalence for contact dermatitis is $20.1 \%$ [19], while for plant-induced contact dermatitis a retrospective study (2006-2009) from the Dermatology Department "St. Spiridon" Hospital, lasi in Romania, included 9059 patients with 353 patients being diagnosed with contact dermatitis (i.e., showing a rather low overall prevalence of 3.89\%); of these patients, 92 (i.e., $26.14 \%$ ) showed a contact dermatitis reaction to plants (marigold $30 \%$, chamomile $20 \%$, and comfrey $17.5 \%$ ) [20]. In a retrospective study analyzing patch test data of the IVDK from 2007 to 2016, Bauer et al. revealed that florists reacted significantly more frequently to Compositae Mix I and II (CM I: $8.7 \%$; CM II 10.6\%) than cooks (CM I: $2.1 \%$; CM II: $0.8 \%$ ) or controls (CM I: 1.3\%; CM II: 1.2\%) [13]. They concluded that florists and related occupations such as gardeners, horticultural workers, flower binders, and seller of fruits, vegetables, and flowers are at considerable risk to acquire occupational contact allergy to Asteraceae plants, fruits, and vegetables [13].

If patient history suggests exposure to plants, additional patch testing for plant compounds (compositae mix) in children was even recommended in a recent EAACl position paper [21], though it was also strongly advised against patch testing of plants known to be irritants such as the Brassicaceae family [21]. The compositae mix has a higher efficacy regarding the detection rate of Asteraceae allergy compared to the previously used SL mix [22]. However, as indicated by Jacob et al., it needs to be kept in mind that the compositae mix consists of short ether extracts of 5 plants (Arnica montana L., Asteraceae, Matricaria chamomilla L., Asteraceae, Tanacetum parthenium L., Asteraceae, Tanacetum vulgare L., Asteraceae, and Achillea millefolium L., Asteraceae) being produced without a standardized manufacturing protocol and chemical profile and thus reproducibility is not guaranteed. Therefore, the development, validation, and commercial marketing of an Asteraceae mix based on pure and standardized ingredients such as the SL Mix II proposed by Jacob et al. [23] might help to further improve the diagnostic in the future.

One elegant approach to review ACD to plants and to classify the most relevant chemical allergens contributing to plant-induced ACD was provided by Rozas-Muñoz et al. and is based on the 5 major families of chemical sensitizers: alpha-methylenegamma-butyrolactones, quinones, phenol derivatives, terpenes, and miscellaneous structures (disulfides, isothiocyanates, and polyacetylenic derivates) [24]. To classify the sensitizers according to their chemical structure might help to provide a more rationale understanding of cross-reactions between apparently unrelated plant genera. 
- Table 1 Sensitizing plant compounds (selected).

\begin{tabular}{|c|c|c|c|}
\hline $\begin{array}{l}\text { Patch test compound } \\
\text { (= not plant derived) }\end{array}$ & Plant family & Plant species & $\begin{array}{l}\text { Prevalence (\%) } \\
\text { according to NACDG 2011-12 [13] or } \\
\left({ }^{*}\right) \text { 2013-2014 [14] or } \\
\text { (+) IVDK [11] or } \\
\text { (\#) de Groot [15] }\end{array}$ \\
\hline \multicolumn{3}{|l|}{ Fragrance mix I } & \multirow{9}{*}{$\begin{array}{l}12.1 \\
{ }^{*} 11.9 \\
(+9.1)\end{array}$} \\
\hline - Amyl cinnamal & \multicolumn{2}{|c|}{ e.g., Cinnamomum verum J.Presl (Lauraceae) } & \\
\hline - Cinnamyl alcohol & \multicolumn{2}{|c|}{ e.g., Styrax L. (Styracaceae) } & \\
\hline - Cinnamal & \multicolumn{2}{|c|}{ e.g., Cinnamomum verum J.Presl (Lauraceae) } & \\
\hline - Eugenol & \multicolumn{2}{|c|}{ e.g., Syzygium aromaticum (L.) Merr. \& L. M.Perry (Myrtaceae) } & \\
\hline - Geraniol & \multicolumn{2}{|c|}{ e.g., Cymbopogon martini (Roxb.) Wats. (Poaceae) } & \\
\hline - Hydroxycitronellal & \multicolumn{2}{|c|}{ e.g., Piper nigrum L. (Piperaceae) } & \\
\hline - Isoeugenol & \multicolumn{2}{|c|}{ e.g., Myristica fragrans Houtt. (Myristicaceae) } & \\
\hline - Oak moss absolute & \multicolumn{2}{|c|}{ Evernia prunastri (L.) Ach. (Parmeliaceae) } & \\
\hline Peru balsam & Fabaceae & Myroxylon balsamum (L.) Harms & $\begin{array}{l}7.9 \\
* 7.2 \\
(+7.2)\end{array}$ \\
\hline \multicolumn{3}{|l|}{ Fragrance mix II } & \multirow{7}{*}{$\begin{array}{l}5.2 \\
* 5.7 \\
(+4.6)\end{array}$} \\
\hline - Citronellol & e.g., Rosa L. (R & & \\
\hline - Citral & \multicolumn{2}{|c|}{$\begin{array}{l}\text { Solanum lycopersicum L. (Solanaceae) + Cymbopogon citratus (DC.) } \\
\text { Stapf (Poaceae) }\end{array}$} & \\
\hline \multicolumn{3}{|l|}{ - Coumarin } & \\
\hline $\begin{array}{l}\text { - (Hydroxyisohexyl 3-cyclo- } \\
\text { hexene carboxaldehyde) }\end{array}$ & \multicolumn{2}{|c|}{ e.g., Dipteryx odorata (Aubl.) Willd. (Fabaceae) } & \\
\hline - Farnesol & \multicolumn{2}{|c|}{ e.g., Vachellia farnesiana (L.) Wight \& Arn. (Fabaceae) } & \\
\hline - Alpha-hexyl-cinnamal & \multicolumn{2}{|c|}{ e.g., Matricaria chamomilla L. (Asteraceae) } & \\
\hline Cinnamic aldehyde & Lauraceae & Cinnamomum verum J.Presl & $\begin{array}{l}3.9 \\
* 4.2\end{array}$ \\
\hline Colophony & \multicolumn{2}{|c|}{ Sap of coniferous trees such as pines, junipers, firs, and cedars } & $\begin{array}{l}2.3 \\
{ }^{*} 1.9\end{array}$ \\
\hline \multirow[t]{4}{*}{ Compositae mix } & \multirow[t]{4}{*}{ Asteraceae } & $\begin{array}{l}\text { Tanacetum vulgare (L.) } \\
\text { Arnica montana (L.) }\end{array}$ & \multirow[t]{4}{*}{$\begin{array}{l}1.9 \\
* 1.7\end{array}$} \\
\hline & & $\begin{array}{l}\text { Tanacetum parthenium (L.) } \\
\text { Sch. Bip. }\end{array}$ & \\
\hline & & Matricaria chamomilla (L.) & \\
\hline & & Achillea millefolium (L.) & \\
\hline Cocamidopropyl betaine & Arecaceae & Cocos nucifera (L.) & $\begin{array}{l}1.4 \\
{ }^{*} 1.6\end{array}$ \\
\hline Majantole & Asparagaceae & Convallaria majalis L. & 1.3 \\
\hline Cocamide DEA & Arecaceae & Cocos nucifera (L.) & $\begin{array}{l}0.9 \\
{ }^{*} 0.9\end{array}$ \\
\hline Tea tree oil & Myrtaceae & $\begin{array}{l}\text { Melaleuca alternifolia } \\
\text { (Maiden \& Betche) Cheel }\end{array}$ & $\begin{array}{l}0.9 \\
{ }^{*} 0.9 \\
(\# 2.7)\end{array}$ \\
\hline $\begin{array}{l}\text { Canaga odorata oil } \\
\text { (ylang ylang) }\end{array}$ & Annonaceae & $\begin{array}{l}\text { Cananga odorata } \\
\text { (Lam.) Hook.f. \& Thomson }\end{array}$ & $\begin{array}{l}0.7 \\
* 1.2 \\
(+2.4) \\
(\# 2.6)\end{array}$ \\
\hline
\end{tabular}


- Table 1 Continued

\begin{tabular}{|c|c|c|c|}
\hline $\begin{array}{l}\text { Patch test compound } \\
\text { (= not plant derived) }\end{array}$ & Plant family & Plant species & $\begin{array}{l}\text { Prevalence (\%) } \\
\text { according to NACDG 2011-12 [13] or } \\
\left({ }^{*}\right) \text { 2013-2014 [14] or } \\
\text { (+) IVDK [11] or } \\
\text { (\#) de Groot [15] }\end{array}$ \\
\hline \multicolumn{3}{|l|}{ Sesquiterpene lactone mix } & \multirow{4}{*}{$\begin{array}{l}0.7 \\
{ }^{*} 0.9\end{array}$} \\
\hline - Alantolactone & \multirow[t]{3}{*}{ Asteraceae } & e.g., Inula helenium L. & \\
\hline - Dehydrocostuslactone & & $\begin{array}{l}\text { e.g., Saussurea costus (Falc.) } \\
\text { Lipsch. }\end{array}$ & \\
\hline - Costunolide & & $\begin{array}{l}\text { e.g., Saussurea costus (Falc.) } \\
\text { Lipsch. }\end{array}$ & \\
\hline Carvone & \multicolumn{2}{|c|}{$\begin{array}{l}\text { Essential oil found e.g., in Carum carvi L. (Apiaceae), Mentha spicata L. } \\
\text { (Lamiaceae), Anethum graveolens L. (Apiaceae) }\end{array}$} & $\begin{array}{l}0.6 \\
{ }^{*} 0.7\end{array}$ \\
\hline Jasminum officinale oil & Oleaceae & Jasminum grandiflorum L. & $\begin{array}{l}0.4 \\
{ }^{*} 0.5\end{array}$ \\
\hline Mentha piperita oil & Lamiaceae & Mentha × piperita L. & $\begin{array}{l}0.4 \\
{ }^{*} 0.6\end{array}$ \\
\hline Lavandula angustifolia oil & Lamiaceae & Lavandula angustifolia Mill. & $\begin{array}{l}0.4 \\
{ }^{*} 0.3\end{array}$ \\
\hline $\begin{array}{l}\text { D-Limonene (precursor to } \\
\text { carvone) }\end{array}$ & Rutaceae & Citrus trees & 0.2 \\
\hline
\end{tabular}

\section{Recent Advances in Understanding the Immunological Mechanisms Underlying Plant Contact Dermatitis}

The pathomechanisms involved in the development of ACD in general have recently been reviewed in more detail $[25,26]$. In brief, contact sensitizers are of low molecular weight (so-called haptens) and therefore need to bind to proteins to become immunogenic. Due to their low molecular weight (MW), they usually easily penetrate the epidermis, where they activate keratinocytes and innate immune cells to generate a pro-inflammatory cytokine milieu. After uptake of the sensitizer by immature dendritic cells (DCs), the DCs start to maturate and migrate to the local lymph node, where the antigen is presented in the context of MHC-1 and co-stimulatory molecules to naive $T$ cells. The $T$ cells start to maturate, proliferate, and migrate back into the skin. A second contact with the same sensitizer leads to the activation of the primed CD8+ T cells and the killing of cells that present the sensitizer in the context of MHC-1 such as keratinocytes. The clinical symptoms are erythema and eczema formation.

Regarding the mechanism underlying the inflammatory response to lattices of plants from the Euphorbiaceae family, a recent study showed that the serine protease mauritanicain and phorbol-12-myristate-13-acetate (PMA) modulate the release of the pro-inflammatory cytokine IL-8 in fibroblasts and the human keratinocyte cell line $\mathrm{HaCaT}$ in a protease activated receptor-dependent manner after in vitro stimulation for $60 \mathrm{~min}$ [27]. This study is in line with a previous work by Domsalla and Melzig, who showed that a combination of proteases and PMA promotes inflammatory responses in the human monocyte-like cell line U937
[28]. This indicates that plant compounds can even enhance the pro-inflammatory cytokine milieu necessary for the initial maturation of DCs and thereby promote the sensitization process.

Interestingly, the bioactive plant compound magnoflorine, isolated from Tinospora crispa L., Menispermaceae, was recently reported to enhance lipopolysaccharide (LPS) mediated pro-inflammatory responses in U937-macrophages via a MyD88-dependent pathway [29]. Treatment of U937 cells with magnoflorine alone had no effect on cytokine production (tumor necrosis factor alpha, interleukin 1 beta, prostaglandin E2). However, synergistically upregulated toll-like receptor 4 (TLR4), and MyD88 expression levels, mitogen-activated protein kinase/phosphoinositide 3kinase (MAPK/PI3K) induced upregulation of NF-KB signaling and enhanced cytokine production was observed when LPS was added to magnoflorine treatment [29]. In addition, T. crispa extract was shown to enhance neutrophil migration and activation as well as $\mathrm{T}$ cell proliferation and pro-inflammatory cytokine production [30]. This indicates that while T. crispa extract is used orally for the treatment of diabetes type II [31], magnoflorine might also enhance the sensitization process in contact dermatitis if mixed with sensitizing plant compounds and applied topically, since both neutrophils [32] and macrophages [33] as well as the TLR4 pathway [34,35] are known to be crucially involved in the initial generation of a pro-inflammatory cytokine micromilieu resulting in enhanced sensitization and ACD. 


\section{Case Reports for Plant Contact Dermatitis}

Recently, one of the few worksite-based studies addressing contact dermatitis to tulips was published [36], showing that of the 164 workers tested, $29.3 \%$ (i.e., 48 workers), were clinically suspected to have contact dermatitis with hand eczema being the most common clinical pattern identified. Interestingly, 17 of these workers showed positive reactions to patch tests with tulip plant (bulb) extracts or alpha-methylene-gamma-butyrolactone, with 12 reacting to both, 3 to alpha-methylene-gamma-butyrolactone only, and 2 to tulip bulb extract only. Importantly, healthy controls were negative for the patch test, ruling out irritancy of the patch test substances. This indicates that tulipalin A (alphamethylene-gamma-butyrolactone) is the main antigen responsible for the dermatitis. In addition, the 2 workers reacting only to the tulip bulb extract show that further studies are still necessary to determine the exact chemical composition of tulip plants and their sensitizing agents [36].

One example of $A B C D$ reaction to tulips was reported in an early publication by Hausen et al. [37]. A seedsman showing a sensitization against tulip bulbs presented with an initial reaction restricted to the fingers but then developed dermatitis spread over the whole body despite strict avoidance of direct contact with tulips. Despite clearance of the dermatitis, he suffered from a recurrence of $A B C D$ after being in a room for $1 \mathrm{~h}$ with a vase of tulip flowers in a side room, indicating that he developed an ACBD to tulips [37].

Another-so far rare (only 2 cases reported)-case of ACD was attributed to jagua dye used for temporary tattoos [38, 39]. Up to now, mostly beneficial effects of extracts from the Amazonian Genipa americana L., Rubiaceae, fruit and especially of its bioactive compound genipin (e.g., as an alternative to synthetic food dye) [40] or in traditional medicine to treat small wounds, skin disorders, anemia, and to induce abortions but also as insect repellent, have been reported in South America and China [39]. In 2 cases, the nontoxic fruit extract, which is long used in the indigenous population for body tattoos (both permanent and temporary) without known cases of adverse reactions, was reported to induce ACD after repeated application of jagua tattoo dye preparations on the skin. This indicates that although jagua dye is claimed to be a "safe and natural" replacement for henna dyes, the incidence of patients suffering from ACD to nonpermanent tattoos might increase with the rising use of these dyes. Interestingly, henna dyes, which are also known to result in ACD when used for nonpermanent tattoos, are usually problematic due to the addition of the sensitizer para-phenylene diamine, which is used to enhance the black coloring of henna [41], while pure henna itself seems to be non-sensitizing with rare cases showing sensitization to lawsone (2-hxdroxy-1,3-naphtoquinone) [42].

In a 12-y-old girl, the first nonoccupational-induced contact dermatitis to Verbascum thapsus L., Scrophulariaceae, was recently described by Echaiz et al. [43]. Though the authors could not exclude that the dermatitis was attributable to the irritant properties of $V$. thapsus, they also reported a simultaneous $A C D$ reaction to members of the Asteraceae family and a positive patch test to the compositae mix [43].

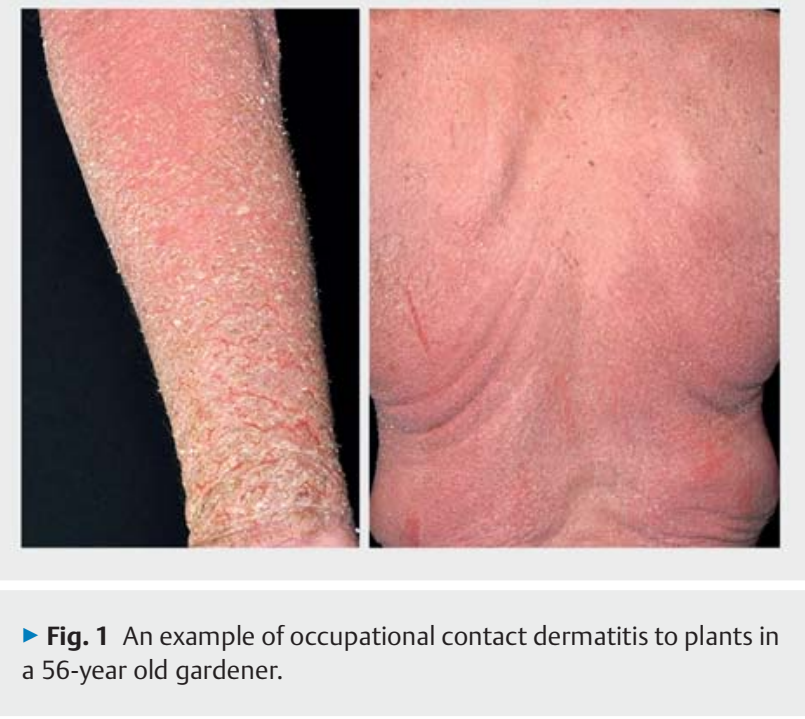

An article reviewing the common causes of ABCD in the USA with the Asteraceae and Anacardiaceae family being the major plant related causes was recently published by Schloemer et al. [44]. The exposure to toxic, phototoxic, and allergic SLs in Asteraceae is known to result in allergic dermatitis (also known as compositae dermatitis), while constant exposure in horticulture leads to occupational dermatitis (see $\boldsymbol{\nabla}$ Fig. 1 for an example of occupational contact dermatitis to plants in a 56-y-old gardener). For Jacobaea vulgaris Gaertn., syn. Senecio jacobaea L., a prominent member of the family of Asteraceae and known by many names like common ragwort, ragweed, St. James wort, Stinking Willy, cushag, or tansy ragwort, a case of contact dermatitis was reported by Pietkiewicz et al. [45]. In addition, as reported by Paulsen and Andersen, $4 \%$ (i.e., 529 of 13,139 patients tested) were sensitized to Asteraceae, and 95 (18\% of these) were monosensitized [46]. Interestingly, when comparing the periods from 20022008 and 2009-2015, the prevalence of Asteraceae sensitization in the latter was significantly lower [46].

\section{Conclusion}

While the beneficial effects of plant compounds for the treatment of skin disorders are manifold as shown in the other articles of this issue, they can also result in different types of contact dermatitis. This is especially relevant as most people associate the terms "healthy and safe to use" with plant compounds due to their natural origin, leading to an increased utilization be it for homemade remedies or as cosmetics. Thus, plants should be taken into consideration especially when testing for contact sensitizers if a history of plant exposure exists. In addition, since several plant compounds show no positive patch test results when using the standard patch test series or commercial plant extracts, it is important to also test extracts/whole parts of the suspected causative plants directly provided by the respective patient whenever possible. 


\section{Conflict of Interest}

The authors declare no conflicts of interest.

\section{References}

[1] Mortimer S, Reeder M. Botanicals in dermatology: essential oils, botanical allergens, and current regulatory practices. Dermatitis 2016; 27: 317-324

[2] Corazza M, Borghi A, Gallo R, Schena D, Pigatto P, Lauriola MM, Guarneri F, Stingeni L, Vincenzi C, Foti C, Virgili A. Topical botanically derived products: use, skin reactions, and usefulness of patch tests. A multicentre Italian study. Contact Dermatitis 2014; 70: 90-97

[3] Hausen BM, Reichling J, Harkenthal M. Degradation products of monoterpenes are the sensitizing agents in tea tree oil. Am J Contact Dermat 1999; 10: 68-77

[4] Matura M, Goossens A, Bordalo O, Garcia-Bravo B, Magnusson K, Wrangsjö K, Karlberg AT. Oxidized citrus oil (R-limonene): a frequent skin sensitizer in Europe. J Am Acad Dermatol 2002; 47: 709-714

[5] European Commission, Directorate General for Health \& Consumers. Opinion on fragrance allergens in cosmetic products. Brussels: European Commission; 2012. Available at http://dx.publications.europa.eu/ doi:10.2772/77628. Accessed January 15, 2018

[6] Rudbäck J, Bergström MA, Börje A, Nilsson U, Karlberg AT. $\alpha$-Terpinene, an antioxidant in tea tree oil, autoxidizes rapidly to skin allergens on air exposure. Chem Res Toxicol 2012; 25: 713-721

[7] Kern S, Granier T, Dkhil H, Haupt T, Ellis G, Natsch A. Stability of limonene and monitoring of a hydroperoxide in fragranced products. Flavour Fragr ] 2014; 29: 277-286

[8] Gilissen L, Huygens S, Goossens A. Allergic contact dermatitis caused by topical herbal remedies: importance of patch testing with the patients' own products. Contact Dermatitis 2018; 78: 177-184

[9] Aberer W. Contact allergy and medicinal herbs. J Dtsch Dermatol Ges J Ger Soc Dermatol JDDG 2008; 6: 15-24

[10] Mitchell JP, Rook A. Botanical Dermatology: Plants and Plant Products injurous to the Skin. Vancouver: Greengrass Ltd.; 1979

[11] Mahler V, Geier J, Schnuch A. Current trends in patch testing - new data from the German Contact Dermatitis Research Group (DKG) and the Information Network of Departments of Dermatology (IVDK). JDDG J Dtsch Dermatol Ges 2014; 12: 583-592

[12] Paulsen E, El-Houri RB, Andersen KE, Christensen LP. Parthenolide in Danish biodynamic and organic milk: a new source of exposure to an allergenic sesquiterpene lactone. Contact Dermatitis 2018; 79: 208-212

[13] Warshaw EM, Maibach HI, Taylor JS, Sasseville D, DeKoven JG, Zirwas M], Fransway AF, Mathias CGT, Zug KA, DeLeo VA, Fowler JF, Marks JG, Pratt MD, Storrs F], Belsito DV. North American contact dermatitis group patch test results: 2011-2012. Dermatitis 2015; 26: 49-59

[14] DeKoven JG, Warshaw EM, Belsito DV, Sasseville D, Maibach HI, Taylor JS, Marks JG, Fowler JF, Mathias CGT, DeLeo VA, Pratt MD, Zirwas MJ, Zug KA. North American Contact Dermatitis Group patch test results 20132014. Dermatitis 2017; 28: 33-46

[15] de Groot AC, Schmidt E. Essential oils, part IV: contact allergy. Dermatitis 2016; 27: 170-175

[16] Sanvido O, Schmid K, FitzGerald RE, Roth N, Wilks MF, Bormann P, Hopf NB. A quantitative risk assessment for skin sensitizing plant protection products: linking derived no-effect levels (DNELs) with agricultural exposure models. Regul Toxicol Pharmacol 2018; 98: 171-183

[17] Paulsen E, Thormann H, Vestergaard L. Eucalyptus species as a cause of airborne allergic contact dermatitis. Contact Dermatitis 2018; 78: 301303

[18] Guo S, Jiang JF, Tan C. Lichenoid contact dermatitis induced by Semen Sinapis albae. J Investig Allergol Clin Immunol 2018; 28: 350-352
[19] Alinaghi F, Bennike NH, Egeberg A, Thyssen JP, Johansen JD. Prevalence of contact allergy in the general population: a systematic review and meta-analysis. Contact Dermatitis 2019; 80: 77-85

[20] Statescu L, Branisteanu D, Dobre C, Solovastru LG, Vasilca A, Petrescu Z, Azoicai D. Contact dermatitis - epidemiological study. Maedica (Buchar) 2011; 6: 277-281

[21] Spek FB de W der, Darsow U, Mortz CG, Orton D, Worm M, Muraro A Schmid-Grendelmeier P, Grimalt R, Spiewak R, Rudzeviciene O, Flohr C, Halken S, Fiocchi A, Borrego LM, Oranje AP. EAACI position paper for practical patch testing in allergic contact dermatitis in children. Pediatr Allergy Immunol 2015; 26: 598-606

[22] von der Werth JM, Ratcliffe J, English JS. Compositae mix is a more sensitive test for Compositae dermatitis than the sesquiterpene lactone mix. Contact Dermatitis 1999; 40: 273-276

[23] Jacob M, Brinkmann J, Schmidt T]. Sesquiterpene lactone mix as a diagnostic tool for Asteraceae allergic contact dermatitis: chemical explanation for its poor performance and Sesquiterpene lactone mix II as a proposed improvement. Contact Dermatitis 2012; 66: 233-240

[24] Rozas-Muñoz E, Lepoittevin JP, Pujol RM, Giménez-Arnau A. Allergic contact dermatitis to plants: understanding the chemistry will help our diagnostic approach. Actas Dermosifiliogr 2012; 103: 456-477

[25] Martin SF, Rustemeyer T, Thyssen JP. Recent advances in understanding and managing contact dermatitis. F1000Res 2018; 7: 810

[26] Esser PR, Martin SF. Pathomechanisms of contact sensitization. Curr Allergy Asthma Rep 2017; 17: 83

[27] Guenther F, Maus D, Hedtrich S, Melzig MF. Serine protease Mauritanicain from Euphorbia mauritanica and phorbol-12-myristate-13-acetate modulate the IL- 8 release in fibroblasts and $\mathrm{HaCaT}$ keratinocytes. Planta Med 2018. doi:10.1055/a-0735-9911

[28] Domsalla A, Melzig MF. Enhancement of protease-induced IL-6 release in monocytic U-937 cells by phorbol-12-myristate-13-acetate. Inflamm Res 2012; 61: 1125-1129

[29] Haque MA, Jantan I, Harikrishnan H, Wahab SMA. Magnoflorine enhances LPS-activated pro-inflammatory responses via MyD88-dependent pathways in U937 macrophages. Planta Med 2018; 84: 1255-1264

[30] Ahmad W, Jantan I, Kumolosasi E, Bukhari SNA. Immunostimulatory effects of the standardized extract of Tinospora crispa on innate immune responses in Wistar Kyoto rats. Drug Des Devel Ther 2015; 9: 29612973

[31] Ahmad W, Jantan I, Bukhari SNA. Tinospora crispa (L.) Hook. f. \& Thomson: a review of its ethnobotanical, phytochemical, and pharmacological aspects. Front Pharmacol 2016; 7: 59

[32] Weber FC, Németh T, Csepregi JZ, Dudeck A, Roers A, Ozsvári B, Oswald E, Puskás LG, Jakob T, Mócsai A, Martin SF. Neutrophils are required for both the sensitization and elicitation phase of contact hypersensitivity. J Exp Med 2015; 212: 15-22

[33] Dudeck A, Dudeck J, Scholten J, Petzold A, Surianarayanan S, Köhler A, Peschke K, Vöhringer D, Waskow C, Krieg T, Müller W, Waisman A, Hartmann K, Gunzer M, Roers A. Mast cells are key promoters of contact allergy that mediate the adjuvant effects of haptens. Immunity 2011; 34: 973-984

[34] Schmidt M, Raghavan B, Müller V, Vogl T, Fejer G, Tchaptchet S, Keck S, Kalis C, Nielsen PJ, Galanos C, Roth J, Skerra A, Martin SF, Freudenberg MA, Goebeler M. Crucial role for human toll-like receptor 4 in the development of contact allergy to nickel. Nat Immunol 2010; 11: 814-819

[35] Esser PR, Wolfle U, Durr C, von Loewenich FD, Schempp CM, Freudenberg MA, Jakob T, Martin SF. Contact sensitizers induce skin inflammation via ROS production and hyaluronic acid degradation. PLoS One 2012; 7: e41340

[36] Hassan I, Rasool F, Akhtar S, Kamili A, Rather P, Kanth R, Bhat Y, Rather S, Mubashir S, Yaseen A, Bashir S. Contact dermatitis caused by tulips: identification of contact sensitizers in tulip workers of Kashmir Valley in North India. Contact Dermatitis 2018; 78: 64-69 
[37] Hausen BM. Airborne contact dermatitis caused by tulip bulbs. ] Am Acad Dermatol 1982; 7: 500-503

[38] Waton J, Brault F, Laveine E. A putative case of allergic contact dermatitis caused by a jagua tattoo. Contact Dermatitis 2017; 76: 296-297

[39] Bircher A], Sigg R, Hofmeier KS, Schlegel U, Hauri U. Allergic contact dermatitis caused by a new temporary blue-black tattoo dye - sensitization to genipin from jagua (Genipa americana L.) fruit extract. Contact Dermatitis 2017; 77: 374-378

[40] Brauch JE, Zapata-Porras SP, Buchweitz M, Aschoff JK, Carle R. Jagua blue derived from Genipa americana L. fruit: a natural alternative to commonly used blue food colorants? Food Res Int 2016; 89: 391-398

[41] Diepgen T I., Ofenloch R f., Bruze M, Bertuccio P, Cazzaniga S, Coenraads PJ, Elsner P, Goncalo M, Svensson Å, Naldi L. Prevalence of contact allergy in the general population in different European regions. $\mathrm{Br}$ J Dermatol 2016; 174: 319-329
[42] Lee YB, Park SM, Kim JW, Yu DS. Combination treatment of low-fluence Q-switched Nd:YAG laser and oral tranexamic acid for post-inflammatory hyperpigmentation due to allergic contact dermatitis to henna hair dye. J Cosmet Laser Ther 2016; 18: 95-97

[43] Echaiz CF, Ali AA, Cao AQ, Sasseville D. Simultaneous contact dermatitis caused by Asteraceae and Verbascum thapsus. Contact Dermatitis 2017; 76: 316-318

[44] Schloemer JA, Zirwas MJ, Burkhart CG. Airborne contact dermatitis: common causes in the USA. Int J Dermatol 2015; 54: 271-274

[45] Pietkiewicz P, Gornowicz-Porowska J, Bowszyc-Dmochowska M, Dmochowski M. Human dermatitis after skin exposure to Jacobaea vulgaris and spectrum of health hazards induced by this plant to humans and livestock. J Agromedicine 2015; 20: 237-241

[46] Paulsen E, Andersen KE. Clinical patterns of Compositae dermatitis in Danish monosensitized patients. Contact Dermatitis 2018; 78: 185-193 